\title{
Novel Benzo[f]coumarin Derivatives as Probable Acetylcholinesterase Inhibitors: Synthesis, In Vitro, and In Silico Studies for Evaluation of Their Anti-AChE Activity
}

\author{
Zaizafoon Nabeel ${ }^{1}$, Qassim Abdul-Hussein Jaber ${ }^{2^{*}}$, and Nabeel Abed Abdul-Rida ${ }^{3}$ \\ ${ }^{1}$ Department of Chemistry, College of Science, Mustansiriyah University, Baghdad, Iraq \\ ${ }^{2}$ Department of Chemistry, General Directorate of Education in Babylon, Hilla, Iraq \\ ${ }^{3}$ Department of Chemistry, College of Science, University of Qadisiyah, Diwanyiah, Iraq
}

*Corresponding author:

email: qassimjaber99@gmail.com

Received: May 4, 2021

Accepted: August 26, 2021

DOI: $10.22146 /$ ijc. 65663

\begin{abstract}
Novel benzo[f]coumarin derivatives bearing pyrimidine unit were successfully synthesized. The target is to develop novel acetylcholinesterase inhibitors. The benzo[f]coumarin chalcone 4 was prepared via Claisen-Schmidt condensation between 3-acetyl-5,6-benzocoumarin and 4-hydroxybenzaldehyde in the alkaline medium. Then, the cyclocondensation of chalcone 4 with urea, thiourea, and guanidine $\mathrm{HCl}$ in the presence of glacial acetic acid led to the formation of various pyrimidines. Structures of the newly synthesized compounds were characterized by FT-IR, ${ }^{1} H-N M R$, ${ }^{13} \mathrm{C}-\mathrm{NMR}$ spectra, and elemental analysis. The acetylcholinesterase (AChE) inhibitory activity tests were carried out using Ellman's assay and donepezil as a reference drug. The biological activity results revealed that the derivatives 6 and 7 inhibit AChE activity in healthy samples showed that the greater inhibition percentage was found respectively at concentrations of $10^{-4}$ and $10^{-10} \mathrm{M}$ while low inhibition percentage was obtained at $10^{-}$ ${ }^{12}$ and $10^{-4} \mathrm{M}$. AChE showed inhibition constant $\mathrm{Ki}$ in the range of $10^{-4}-10^{-12} \mathrm{M}$ in the presence of maximum and minimum inhibitor concentrations, probably due to variant types of inhibition from non and uncompetitive. In addition, molecular modeling simulations of targeted compounds revealed their mechanism of action as potent inhibitors for the AChE enzyme.
\end{abstract}

Keywords: benzo[f]coumarin; pyrimidine; chalcone; acetylcholinesterase

\section{- INTRODUCTION}

Alzheimer's disease (AD) is known as a neurodegenerative disorder, which appears in older adults with symptoms as loss of memory, a decline in cognitive functions and language skills [1]. According to the cholinergic hypothesis, $\mathrm{AD}$ is mainly related to the level decrease of acetylcholine $(\mathrm{AChE})$ in the brain because of the damage of cholinergic neurons, thus raising the $\mathrm{AChE}$ via inhibition of acetylcholinesterase is one of the effective approaches to treatment AD's symptoms [2-3]. In this context, several AChE inhibitors such as umbelliferone, hymecromone, and ensaculin (I, II, Fig. 1), which belong to the coumarin family, were used as approved therapeutic by the FDA to curb the progression of $\mathrm{AD}$ in early stages [4-6]. In addition, coumarin derivatives have been studied extensively due to their biological activities such as antimicrobial [7], anticancer [8-11], anticoagulant [12], analgesic [13], ulcerogenic [14], antiviral [15], antimalarial [16], antiinflammatory [17-18], antidepressant [19], and antioxidant [20-21] activities, as well as anti-HIV protease [22], acetylcholinesterase [23-24], and monoamine oxidase B (MAO-B) [25] inhibitors. It was worth mentioning that many coumarin derivatives were designed and found to be successful as significant organic fluorescent materials for potential applications in biochemical and biological imaging due to their light emission properties [23]. This work reports the synthesis of new series of benzocoumarin derivatives conjugated with various pyrimidines and their anti-cholinesterase activity evaluation. 


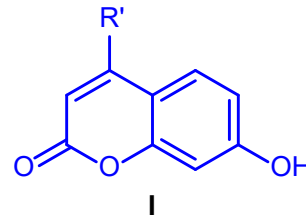

Umbelliferone $\left(\mathrm{R}^{\prime}=\mathrm{H}\right)$ Hymecromone $\left(\mathrm{R}^{\prime}=\mathrm{CH}_{3}\right)$

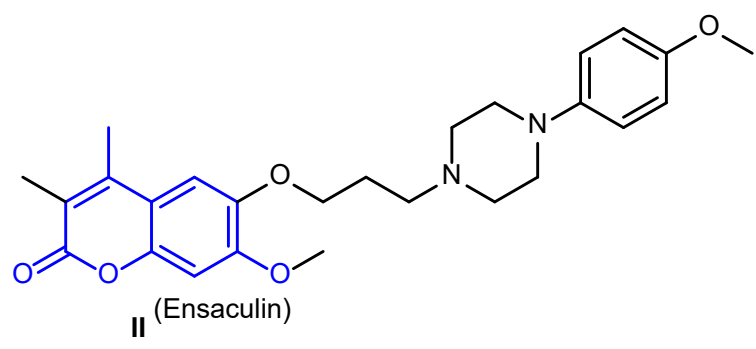

Fig 1. Structures of coumarin derivatives used as acetylcholinesterase inhibitors

\section{- EXPERIMENTAL SECTION}

\section{Materials}

The reagents, including 2-hydroxynaphthal-dehyde, ethyl acetoacetate, piperidine, 4-hydroxy benzaldehyde, urea, thiourea, guanidine $\mathrm{HCl}$, ethanol, and glacial acetic acid, were purchased from Merck and TCI. At the same time, the materials used in the biological evaluation include 5,5-dithio-bis-(2-nitro benzoic acid) (DTNB), serum-blood, sodium phosphate, acetyl thiocholineiodide, and dimethyl sulfoxide (DMSO).

\section{Instrumentation}

Melting points were measured on a Stuart melting point apparatus SMP30 (Büchi Labortechnik AG, Switzerland) and are uncorrected. Infrared (FT-IR) spectra were recorded ( $\mathrm{KBr}$ discs) on a Shimadzu FT-IR 8201 PC spectrophotometer. NMR data were obtained on Varian INOVA $\left({ }^{1} \mathrm{H}, 500 \mathrm{MHz} ;{ }^{13} \mathrm{C}, 125.65 \mathrm{MHz}\right)$ spectrometers used TMS as internal standard and DMSO$\mathrm{d}_{6}$ solvent on the $\delta$ scale in ppm. Analytical silica gel TLC plates 60 F254 were purchased from Merck. Elemental analyses (CHN) were carried out using Vario Elemental Analyzer 3000 (Shimadzu, Japan). All reagents were obtained from commercial suppliers and were used without further purification.

\section{Procedure}

\section{Synthesis}

Preparation of 3-acetyl-5,6-benzocoumarin (3). To a stirred solution of 2-hydroxynaphthaldehyde $\mathbf{1}(1.722 \mathrm{~g}$, $0.01 \mathrm{~mol})$ in absolute $\mathrm{EtOH}(15 \mathrm{~mL})$ containing tree drops of piperidine, ethyl acetoacetate $2(1.30 \mathrm{~g}, 0.01 \mathrm{~mol})$ was added and the mixture was refluxed until formed the precipitate. The solid result was collected by filtration, washed with water, dried, and recrystallized from EtOH to get compound 3. Physical state: yellow crystals, yield: 93\%, m.p. $186-188^{\circ} \mathrm{C}, \mathrm{R}_{\mathrm{f}}=0.59$ (Hexane:Ethyl acetate 7:3). FT-IR $\left(\mathrm{KBr}, \mathrm{cm}^{-1}\right): v 1211(\mathrm{C}-\mathrm{O}), 1450,1558,1612$ $(\mathrm{C}=\mathrm{C}), 1735,1681(\mathrm{C}=\mathrm{O}), 3031,2931(\mathrm{C}-\mathrm{H}) .{ }^{1} \mathrm{H}-\mathrm{NMR}$ (DMSO-d ${ }_{6}, \delta$, ppm): $\delta 8.10$ (s., $\left.1 \mathrm{H}, \mathrm{H}-4\right), 7.89$ (d, $J=7.9$ $\mathrm{Hz}, 1 \mathrm{H}, \mathrm{H}-5), 7.84(\mathrm{~d}, J=7.7 \mathrm{~Hz}, 1 \mathrm{H}, \mathrm{H}-8), 7.68(\mathrm{~m}, 1 \mathrm{H}$, H-6), 7.49 (m, 1H, H-7), 7.39 (d, $J=8.4 \mathrm{~Hz}, 1 \mathrm{H}, \mathrm{H}-9$ ), $7.04(\mathrm{~d}, J=7.9 \mathrm{~Hz}, 1 \mathrm{H}, \mathrm{H}-10), 2.21$ (s, 3H, Me). ${ }^{13} \mathrm{C}-\mathrm{NMR}$ $\left(\right.$ DMSO- $\left.\mathrm{d}_{6}\right): \delta 172.0\left(\mathrm{C}=\mathrm{O}_{\text {ketone }}\right), 161.7 \quad\left(\mathrm{C}=\mathrm{O}_{\text {coum. }}-2\right)$, 155.5 ( $\mathrm{C}_{\text {coum. }}$-10a), 137.6 ( $\left.\mathrm{C}_{\text {coum. }}-4\right), 135.1,134.1,131.1$, $130.7,130.2,129.0,128.3,120.6,120.4,116.8,113.4$ $\left(\mathrm{C}_{\text {coum. }}\right), 29.5(\mathrm{Me})$. Anal. calculated for $\mathrm{C}_{15} \mathrm{H}_{10} \mathrm{O}_{3}$ : C, 75.62; H, 4.23; Found; C, 74.35; H, 4.06.

Preparation of 2-(3-(4-hydroxyphenyl)acryloyl)3H-benzo[f]chromen-3-one (4). A solution of compound 3 (1.191 g, $0.005 \mathrm{~mol}$ ) in ethanol and 4hydroxybenzaldehyde $(0.61 \mathrm{~g}, 0.005 \mathrm{~mol})$ was stirred at $50{ }^{\circ} \mathrm{C}$ for $6 \mathrm{~h}$ in the presence of piperidine $(0.5 \mathrm{~mL}$ ) (TLC check). After cooling, the reaction mixture was stirred for $1 \mathrm{~h}$ and then kept in the refrigerator for $24 \mathrm{~h}$, the formed solid was filtered and crystallized from ethanol to get compound 4. Brown crystals, yield: 73\%, m.p. 203-205 ${ }^{\circ} \mathrm{C}, \mathrm{R}_{\mathrm{f}}=0.58$ (Hexane:Ethyl acetate 8:2). IR spectrum, $v, \mathrm{~cm}^{-1}$ : $1218(\mathrm{C}-\mathrm{O}), 1604(\mathrm{C}=\mathrm{C}), 1675$ $(\mathrm{C}=\mathrm{O}), 1738(\mathrm{C}=\mathrm{O}), 3471(\mathrm{OH}) .{ }^{1} \mathrm{H}-\mathrm{NMR}$ spectrum, $\delta$, ppm: 9.80 (s., $1 \mathrm{H}, \mathrm{OH}$ ), 8.42 (s., $1 \mathrm{H}, \mathrm{H}-4$ ), 8.07 (d, $J=7.2$ $\mathrm{Hz}, 1 \mathrm{H}, \mathrm{H}-5), 8.04$ (d, $J=7.6 \mathrm{~Hz}, 1 \mathrm{H}, \mathrm{H}-8), 7.86$ (d, $J=$ $8.4 \mathrm{~Hz}, 1 \mathrm{H}, \mathrm{H}-13), 7.20$ (d, $J=5.8 \mathrm{~Hz}, 1 \mathrm{H}, \mathrm{H}-12), 7.68-$ $6.76\left(8 \mathrm{H}, \mathrm{H}_{\text {coum. }} \mathrm{H}_{\text {arom. }}\right){ }^{13} \mathrm{C}-\mathrm{NMR}$ spectrum, $\delta \mathrm{C}$, ppm: $171.1\left(\mathrm{C}=\mathrm{O}_{\text {chalcone }}\right), 159.5\left(\mathrm{C}=\mathrm{O}_{\text {coum. }}-2\right), 157.8(\mathrm{C}-\mathrm{OH})$, 149.1 ( $\left.\mathrm{C}_{\text {coum. }}-10 \mathrm{a}\right), 138.5$ ( $\left.\mathrm{C}_{\text {coum. }}-4\right), 135.1,134.1,131.1$, $130.7,130.2,129.5,128.7,126.7,125.1,124.8,121.0$, 120.0, $119.2\left(\mathrm{C}_{\text {coum. }+} \mathrm{C}_{\text {arom. }}\right)$. Anal. calculated for $\mathrm{C}_{22} \mathrm{H}_{14} \mathrm{O}_{4}$ : 
C, 77.18; H, 4.12; Found; C, 77.56; H, 4.29.

\section{Synthesis of 2-(2-oxo-6-(4-hydroxyphenyl)pyrimi} din-4-yl)-3H-benzo[f]chromen-3-one (5). A mixture of chalcone 4 ( $4.74 \mathrm{~g}, 0.01 \mathrm{~mol})$, urea $(0.72 \mathrm{~g}, 0.012 \mathrm{~mol})$ in $20 \mathrm{~mL}$ of absolute ethanol containing glacial acetic acid $(0.5 \mathrm{~mL})$ was refluxed for $7 \mathrm{~h}$ (TLC check). After cooling, the reaction mixture was poured onto ice-water $(50 \mathrm{~mL})$ with continuous stirring. The solid obtained was filtered and crystallized from dry ethanol to get compound $\mathbf{5}$. White crystals, yield: $68 \%$, m.p. $223-225{ }^{\circ} \mathrm{C}, \mathrm{R}_{\mathrm{f}}=0.54$ (Hexane:Ethyl acetate 7:3). IR spectrum, $v, \mathrm{~cm}^{-1}: 1218$ (CO), $1635(\mathrm{C}=\mathrm{N}), 1728,1679(\mathrm{C}=\mathrm{O}), 3240(\mathrm{NH}), 3397$ (OH). ${ }^{1} \mathrm{H}-\mathrm{NMR}$ spectrum, $\delta$, ppm: 10.54 (s., $1 \mathrm{H}, \mathrm{NH}$ ), 9.76 (s., $1 \mathrm{H}, \mathrm{OH}), 8.40$ (s., $1 \mathrm{H}, \mathrm{H}-4), 8.08$ (d, $J=7.1 \mathrm{~Hz}$, $1 \mathrm{H}, \mathrm{H}-5), 7.87(\mathrm{~d}, J=7.7 \mathrm{~Hz}, 1 \mathrm{H}, \mathrm{H}-8), 7.86-6.76(8 \mathrm{H}$, $\left.\mathrm{H}_{\text {coum. }+} \mathrm{H}_{\text {arom. }}\right) .{ }^{13} \mathrm{C}-\mathrm{NMR}$ spectrum, $\delta \mathrm{C}$, ppm: $166.8(\mathrm{C}=\mathrm{N})$, 164.0 (C-4 $\left.4_{\text {yyrim. }}\right), 161.4\left(\mathrm{C}=\mathrm{O}_{\text {coum. }}-2\right), 160.3\left(\mathrm{C}=\mathrm{O}_{\text {Pyrim. }}\right)$, 157.9 (C-OH), 153.9 (C-10a coum. $), 143.1$ (C-4 coum. $\left._{\text {co }}\right), 134.9$, 134.2, 130.6, 130.3, 128.6, 127.7, 126.6, 125.1, 124.0, 118.4, $116.1,115.2,115.0\left(\mathrm{C}_{\text {coum. }} \mathrm{C}_{\text {arom. }}\right)$, 101.0 (C-5 $\left.5_{\text {Pyrim. }}\right)$. Anal. calculated for $\mathrm{C}_{23} \mathrm{H}_{14} \mathrm{~N}_{2} \mathrm{O}_{4}: \mathrm{C}, 72.25 ; \mathrm{H}, 3.69 ; \mathrm{N}, 7.33$. Found; C, 71.62; H, 3.24; N, 7.02.

Synthesis of 2-(6-(4-hydroxyphenyl)-2-thioxo-1,2dihydropyrimidin-4-yl)-3H-benzo[f]chromen-3-one

(6). A mixture of chalcone $4(4.74 \mathrm{~g}, 0.01 \mathrm{~mol})$, thiourea $(0.84 \mathrm{~g}, 0.011 \mathrm{~mol})$ in $20 \mathrm{~mL}$ absolute ethanol containing glacial acetic acid $(0.5 \mathrm{~mL})$ was refluxed for $8 \mathrm{~h}$ (TLC check). After cooling, the reaction mixture was poured onto ice-water $(50 \mathrm{~mL})$ with continuous stirring. The solid obtained was filtered and crystallized from dry ethanol to get compound 6 . White crystals, yield: $62 \%$, m.p. $214-216^{\circ} \mathrm{C}, \mathrm{R}_{\mathrm{f}}=0.65$ (Hexane:Ethyl acetate 8:2). IR spectrum, $v, \mathrm{~cm}^{-1}: 1232(\mathrm{C}-\mathrm{O}), 1636(\mathrm{C}=\mathrm{N}), 1745(\mathrm{C}=\mathrm{O})$, $3178(\mathrm{NH}), 3387(\mathrm{OH}) .{ }^{1} \mathrm{H}-\mathrm{NMR}$ spectrum, $\delta$, ppm: 10.65 (s., $1 \mathrm{H}, \mathrm{NH}), 9.58$ (s., $1 \mathrm{H}, \mathrm{OH}), 8.32$ (s., $1 \mathrm{H}, \mathrm{H}-4), 8.01$ (d, $J=6.8 \mathrm{~Hz}, 1 \mathrm{H}, \mathrm{H}-5), 7.94$ (d, $J=7.1 \mathrm{~Hz}, 1 \mathrm{H}, \mathrm{H}-8), 7.68-$ $6.89\left(8 \mathrm{H}, \mathrm{H}_{\text {coum. }} \mathrm{H}_{\text {arom. }}\right), 6.37$ (s., $\left.1 \mathrm{H}, \mathrm{H}-5_{\text {Pyrim. }}\right) .{ }^{13} \mathrm{C}-\mathrm{NMR}$ spectrum, $\delta \mathrm{C}$, ppm: $176.3(\mathrm{C}=\mathrm{S}), 169.3(\mathrm{C}=\mathrm{N}), 161.0(\mathrm{C}-$ $\left.4_{\text {Pyrim. }}\right), 160.4\left(\mathrm{C}=\mathrm{O}_{\text {coum. }}\right), 155.9(\mathrm{C}-\mathrm{OH}), 153.8(\mathrm{C}-10 \mathrm{a}$ coum.), 147.5 (C-4 coum. $\left._{\text {. }}\right), 134.4,134.0,130.2,125.1,124.8$, 118.6, 117.7, $116.1\left(\mathrm{C}_{\text {coum. }} \mathrm{C}_{\text {arom. }}\right), 101.5$ (C-5 $\left.5_{\text {pyrim. }}\right)$. Anal. calculated for $\mathrm{C}_{23} \mathrm{H}_{14} \mathrm{~N}_{2} \mathrm{O}_{4} \mathrm{~S}$ : C, 69.33; H, 3.54; N, 7.03. Found; C, 68.56; H, 3.29; N, 6.78.
Synthesis of 2-(2-amino-6-(4-hydroxyphenyl) pyrimidin-4-yl)-3H-benzo[f]chromen-3-one (7). A mixture of chalcone 4 (4.74 g, $0.01 \mathrm{~mol}$ ), guanidine $\mathrm{HCl}$ $(1.05 \mathrm{~g}, 0.011 \mathrm{~mol})$ in $20 \mathrm{~mL}$ absolute ethanol containing glacial acetic acid $(0.5 \mathrm{~mL})$ was refluxed for $5 \mathrm{~h}$ (TLC check). After cooling, the reaction mixture was poured onto ice-water $(50 \mathrm{~mL})$ with stirring. The resulting solid was filtered and crystallized from ethanol to get the compound 7. White crystals, yield: $55 \%$, m.p. $231-233^{\circ} \mathrm{C}$, $\mathrm{R}_{\mathrm{f}}=0.58$ (Hexane:Ethyl acetate 8:2). IR spectrum, $v, \mathrm{~cm}^{-1}$ : $1211(\mathrm{C}-\mathrm{O}), 1638(\mathrm{C}=\mathrm{N}), 1743(\mathrm{C}=\mathrm{O}), 3256,3235$ $\left(\mathrm{NH}_{2}\right), 3391(\mathrm{OH}) .{ }^{1} \mathrm{H}-\mathrm{NMR}$ spectrum, $\delta$, ppm: 9.42 (s., $1 \mathrm{H}, \mathrm{OH}), 8.29$ (s., $1 \mathrm{H}, \mathrm{H}-4), 7.97$ (d, $J=7.3 \mathrm{~Hz}, 1 \mathrm{H}, \mathrm{H}-$ 5), $7.93(\mathrm{~d}, J=7.5 \mathrm{~Hz}, 1 \mathrm{H}, \mathrm{H}-8), 7.88-6.65(8 \mathrm{H}$, $\left.\mathrm{H}_{\text {coum. } .} \mathrm{H}_{\text {arom. }}\right), 6.45$ (s., $2 \mathrm{H}, \mathrm{NH}_{2}$ ). ${ }^{13} \mathrm{C}-\mathrm{NMR}$ spectrum, $\delta \mathrm{C}$, ppm: $165.2(\mathrm{C}=\mathrm{N}), 163.2\left(\mathrm{C}-2_{\text {Pyrim. }}\right), 161.3\left(\mathrm{C}-4_{\text {Pyrim. }}\right)$, $160.3\left(\mathrm{C}=\mathrm{O}_{\text {coum. }}\right), 157.9(\mathrm{C}-\mathrm{OH}), 153.9$ ( $\left.\mathrm{C}_{\text {coum. }}-10 \mathrm{a}\right)$, $147.9\left(\mathrm{C}-4_{\text {coum. }}\right), 134.2,130.3,129.6,128.6,128.0,127.9$, 127.8, 125.1, 116.3, 116.1 ( $\left.\mathrm{C}_{\text {coum. }} \mathrm{C}_{\text {arom. }}\right)$, 108.7 (C-5 Pyrim. $\left._{\text {. }}\right)$. Anal. calculated for $\mathrm{C}_{23} \mathrm{H}_{15} \mathrm{~N}_{3} \mathrm{O}_{3}: \mathrm{C}, 72.43 ; \mathrm{H}, 3.96 ; \mathrm{N}$, 11.02. Found; C, 71.26; H, 3.79; N, 10.55 .

\section{Determination of AChE activity}

Human serum AChE activity was determined using Ellman et al. [26] method. $50 \mu \mathrm{L}$ of DTNB solution $0.001 \mathrm{M}$ is added to $2.25 \mathrm{~mL}$ of sodium phosphate buffer solution $(\mathrm{pH}=7.3,0.2 \mathrm{M})$, then $10 \mu \mathrm{L}$ of serum was added and mixed well. Two milliliters of the mixture were transferred to a measuring cell $(1 \mathrm{~cm})$. Then, $34 \mu \mathrm{L}$ of acetyl thiocholineiodide (ASChI, $0.06 \mathrm{M}$ ) is added. The changes in absorbency are measured before and after adding the substrate at $430 \mathrm{~nm}$ for $3 \mathrm{~min}$. The enzyme activity is calculated as a concentration in $\mu \mathrm{mol}$ of the substrate hydrolyzed to every $1 \mathrm{~mL}$ of samples in $3 \mathrm{~min}$ and expressed as $\mu \mathrm{mol} / 3 \mathrm{~min} / \mathrm{mL}$.

\section{Determination of the biological activity of newly prepared derivatives}

A stock concentration solution of $0.01 \mathrm{M}$ concentration of each 6 and 7 in Fig. 1 has been prepared. Then, each complex's different concentrations $\left(10^{-2}, 10^{-3}, 10^{-5}, 10^{-7}, 10^{-9}\right.$, and $\left.10^{-11} \mathrm{M}\right)$ were prepared by diluting it with DMSO as a solvent. ChE activity is measured in human serum as follows: 
DTNB solution ( $50 \mu \mathrm{L}, 0.001 \mathrm{M})$ is added to $2.25 \mathrm{~mL}$ of sodium phosphate buffer solution $(\mathrm{pH}=7.3,0.2 \mathrm{M})$, $0.25 \mathrm{~mL}$ of inhibitor was mixed with $2 \mathrm{~mL}$ of the same buffer $10 \mu \mathrm{L}$ of serum is added and mixed well. Two milliliters of the mixture were transferred to a measuring cell $(1 \mathrm{~cm})$, then $34 \mu \mathrm{L}$ of AChI $(0.06 \mathrm{M})$ was added. The changes in absorbency changes are measured after adding the substrate at $430 \mathrm{~nm}$ for $3 \mathrm{~min}$. The inhibition percentage was calculated by comparing the activity between with and without inhibitor under the same conditions according to the equation:

$\%$ Inhibition $=100-\left(\frac{\text { The activity in the presence of inhibitor }}{\text { The activity in the absence of inhibitor }} \times 100\right)$

\section{Determination of the type of inhibition}

Constant concentrations of inhibitors (second higher inhibition and lower inhibition) were used with different concentrations $(0.02,0.04,0.06$, and $0.08 \mathrm{M})$ to study the type of inhibition. These concentrations were prepared using the stock solution of AChI 0.1 M. The enzyme activity was determined with and without the inhibitors using the Lineweaver-Burk-equation by plotting $1 / \mathrm{V}$ vs. $1 /[\mathrm{s}]$ following values were then calculated as follows: 1) $\mathrm{K}_{\mathrm{i}}$, 2) Apparent $\mathrm{V}_{\max }\left(\mathrm{V}_{\text {mapp }}\right)$, 3) Apparent $\mathrm{K}_{\mathrm{m}}\left(\mathrm{K}_{\text {mapp }}\right)$, and 4) type of inhibition.

\section{Molecular docking}

A molecular docking study was carried out using the Autodock 4.2 program [27], while Discovery Studio Visualizer was used to select the best binding mode with the receptor and $3 \mathrm{D}$ interaction poses. The $3 \mathrm{D}$ structures of AChE (PDB 2ACE) were obtained from the Protein Data Bank (www.rcsb.org), followed by separating the cocrystallized ligands and water molecules. Then polar hydrogens were added. Finally, the 3D structures of the tested coumarin analogs were optimized using Gaussian 03 software with the semi-empirical AM1 method.

\section{- RESULTS AND DISCUSSION}

\section{Chemical Structure}

3-Acetyl-5,6-benzocoumarin 3 were successfully prepared from a reaction of 2-hydroxynaphthal-dehyde $\mathbf{1}$ with ethyl acetoacetate $\mathbf{2}$ and few drops of piperidine under reflux conditions. Next, condensation of benzocoumarin derivative 3 with 4-hydroxybenzaldehyde using piperidine as a catalyst was done via reflux to form benzocoumarin chalcone 3 . Later, cyclocondensation of chalcone 4 with urea, thiourea, and guanidine $\mathrm{HCl}$ was done by reflux and using glacial acetic acid as a catalyst to produce various pyrimidine rings. The synthetic methods to the novel compounds are shown in the following Scheme 1.

The structures of compounds 3-7 were confirmed on the basis of elemental analyses as well as spectral data (FT-IR, ${ }^{1} \mathrm{H}-\mathrm{NMR}$, and ${ }^{13} \mathrm{C}-\mathrm{NMR}$ spectra). The FT-IR spectra of the synthesized compounds exhibited absorption bands at $1728-1745 \mathrm{~cm}^{-1}$ due to lactone carbonyl stretching, whereas compounds 3 and 4 showed two bands at 1675 and $1681 \mathrm{~cm}^{-1}$ assignable to carbonyl group stretching of chalcone and ketone, respectively. In addition, hydroxyl group stretching bands were exhibited in the range of $3387-3471 \mathrm{~cm}^{-1}$, other absorption bands assignable to substituents were comprehensively analyzed.

In ${ }^{1} \mathrm{H}-\mathrm{NMR}$ spectra of the compounds 3-7, the protons of the benzocoumarin moiety appeared almost similar pattern. The $\mathrm{C} 4-\mathrm{H}$ of the benzocoumarin moiety was resonated as singlets at $\delta=8.20-8.42 \mathrm{ppm}$. Meanwhile, the range of resonance at $\delta=9.42-9.80 \mathrm{ppm}$ is due to the $\mathrm{O}-\mathrm{H}$ bond. The spectrum of compound 4 exhibited two doublets at $7.20 \mathrm{ppm}$ and $7.86 \mathrm{ppm}$, indicating that the ethylene group in the enone linkage is in a trans-conformation in the chalcone. In addition, the aromatic and other substituents protons were comprehensively analyzed.

In the ${ }^{13} \mathrm{C}-\mathrm{NMR}$ spectra of the compounds 3-7, the carbon atom of the $\mathrm{C}=\mathrm{N}$ group was resonated at the regions $\delta=169.3-165.2 \mathrm{ppm}$, while carbonyl group of benzocoumarin and were resonated at the regions $\delta=$ 161.7-159.5 ppm. The resonances at the regions $\delta=$ $155.0-149.1 \mathrm{ppm}$ and $\delta=147.5-137.6 \mathrm{ppm}$ were assigned to carbon atoms C-10a and C-4 of the benzocoumarin, respectively. In addition, the carbon atoms of the $\mathrm{C}-\mathrm{OH}$ group in the phenol ring was resonated at the regions $\delta$ $=157.9-155.9$. Other aromatic and benzocoumarin atoms and the other substituted were comprehensively analyzed. 

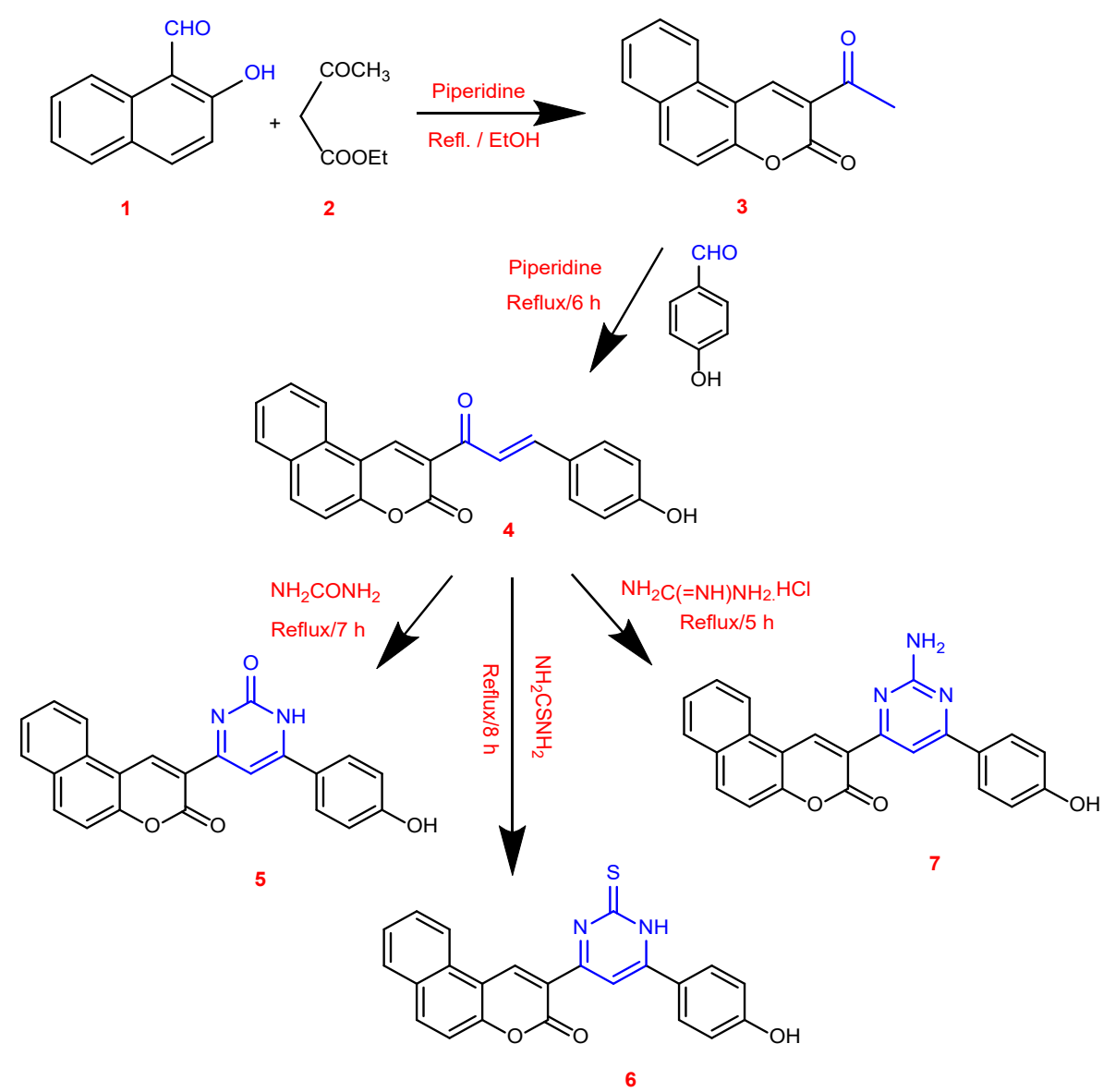

Scheme 1. The experimental steps for synthesizing benzo[f]coumarin derivatives (3-7)

\section{Molecular Docking Results}

In the present work, in silico study was performed using molecular docking simulation in order to test the capability of some synthesized compounds as potential AChE inhibitors. The targeted compounds (5-7) and Donepezil were docked as ligands with the active pocket of AChE (PDB ID: 2ACE) to attain favorable conformation, with the maximum number of interactions and minimal free energy, as shown in Fig. 2-5. The findings of the study, which include binding energies and types of interactions, are shown in Table 1.

Fig. 4 shows 2D and 3D Donepezil's interactions as ligand with the target $2 \mathrm{ACE}$, including $\mathrm{H}$-bond, $\pi-\pi$ and van der Waal's interactions with residues of His398, Cys402, Tyr524, Phe284, and Pro361 amino acids in the active site of AChE with binding energy $-10.6 \mathrm{kcal} / \mathrm{mol}$
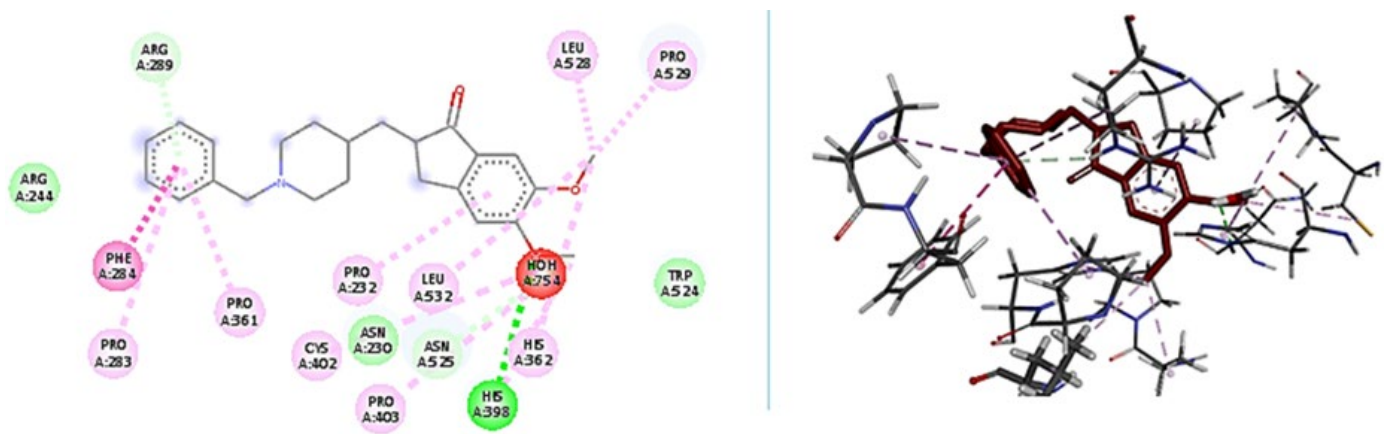

Fig 2. The docking interactions of Donepezil with the catalytic site of AChE enzyme 


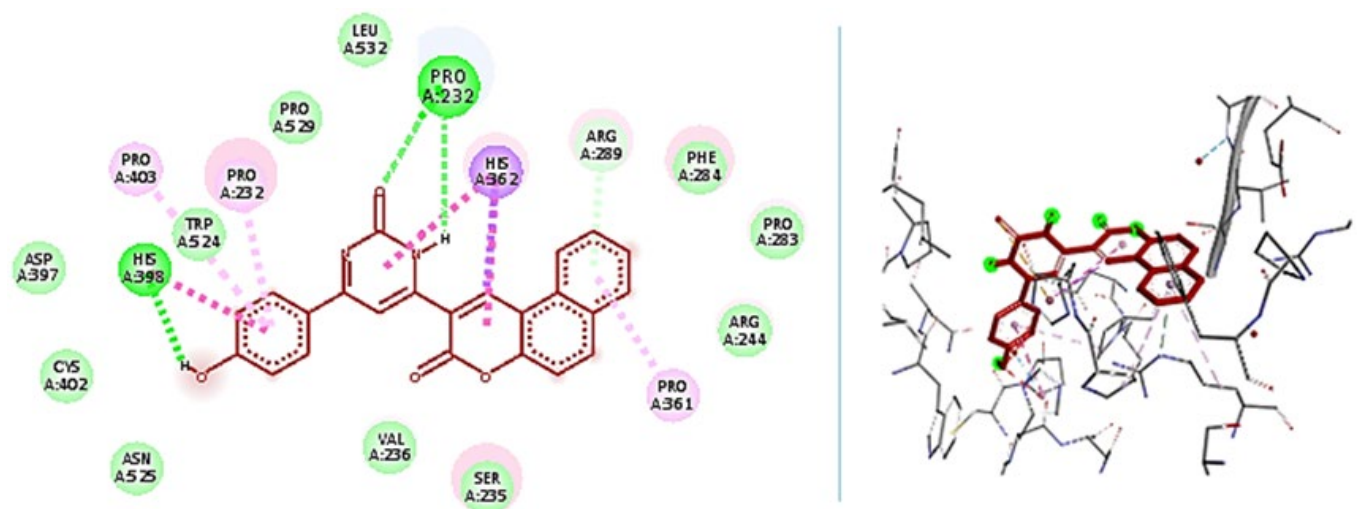

Fig 3. The docking interactions of compound 5 with the catalytic site of AChE enzyme

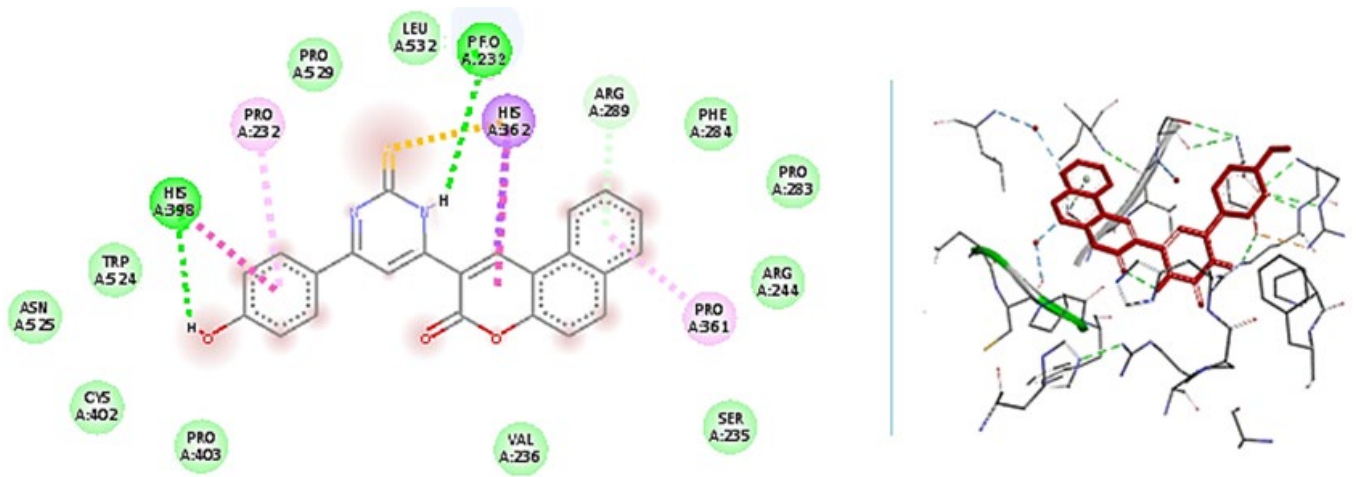

Fig 4. The docking interactions of compound 6 with the catalytic site of AChE enzyme
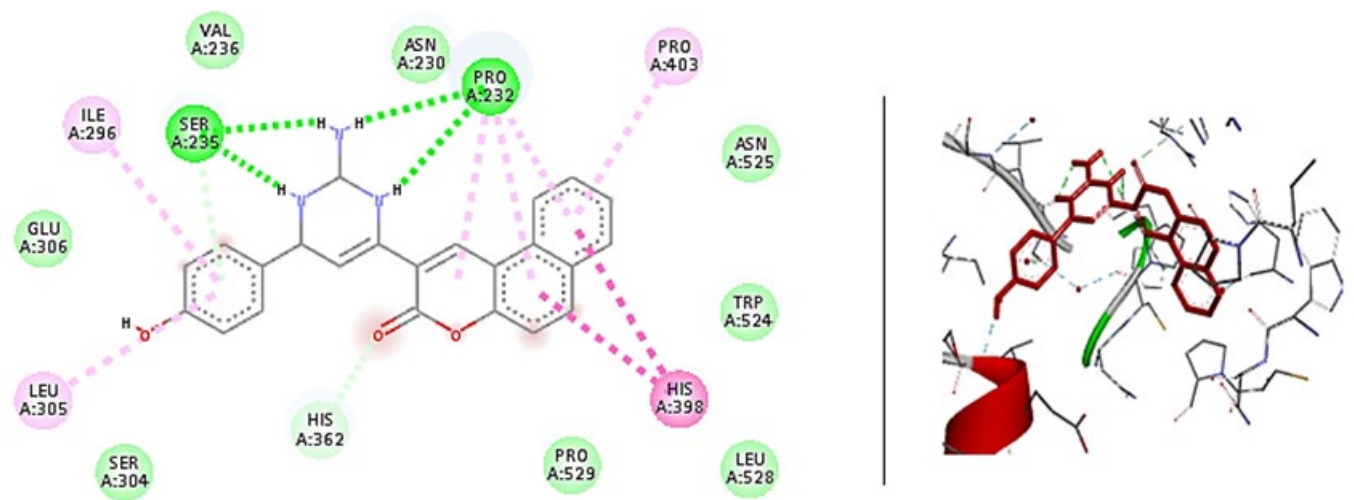

Fig 5. The docking interactions of compound 7 with the catalytic site of AChE enzyme

and distances varying from 2.68 to $3.23 \AA$. The docking simulation of compounds 5-7 had demonstrated stronger electrostatic interactions (van der Waal's, $\pi-\pi$ stacking, and $\mathrm{H}$-bond) with lower docking energies -17.4, 13.6, and $-11.3 \mathrm{kcal} / \mathrm{mol}$, respectively, when compared to the docking score of Donepezil $-10.6 \mathrm{kcal} / \mathrm{mol}$, as shown in Fig. 3-5. Among the other derivatives, derivative 7 formed four $\mathrm{H}$-bond interactions with key amino acids residues: Ser235, Asn230, Pro232, and His398, whereas the other electrostatic interactions formed with His362, Arg289, Arg244, Pro361, Pro232, Pro403, Val236, Leu532, and Phe284. In derivatives 5 and 6, similar binding interactions with active pockets of $2 \mathrm{ACE}$ were observed due to the high homology of binding site residues and other electrostatic interactions formed with residues Cys402, Trp524, and Ala234 amino acids. The huge number of various binding interactions with amino acid residues of the active pocket in the target protein and 
Table 1. Docking results obtained for synthesized coumarin derivatives with acetylcholinesterase (PDB ID: 2ACE)

\begin{tabular}{|c|c|c|c|c|}
\hline Compound & Ligand moiety & Site & Interaction & $\mathrm{E}(\mathrm{kcal} / \mathrm{mol})$ \\
\hline \multirow{5}{*}{5} & $\mathrm{OH}$ & N HIS 398 (A) & H- acceptor & \multirow{5}{*}{-11.3} \\
\hline & $\mathrm{NH}$ & O PRO 232(A) & H- acceptor & \\
\hline & $\mathrm{C}=\mathrm{O}$ & N PRO 232(A) & H- donor & \\
\hline & 6-ring & ARG 289(A) & $\pi-\mathrm{H}$ & \\
\hline & $\mathrm{C}=\mathrm{C}$ & HIS 362(A) & $\pi-\pi, \pi-S i$ & \\
\hline \multirow{5}{*}{6} & $\mathrm{OH}$ & N HIS 398 (A) & H- acceptor & \multirow{5}{*}{-13.6} \\
\hline & $\mathrm{NH}$ & O PRO 232(A) & H- acceptor & \\
\hline & $\mathrm{C}=\mathrm{S}$ & N HIS 362(A) & $\pi$-Sulfur & \\
\hline & 6-ring & ARG 289(A) & $\pi-\mathrm{H}$ & \\
\hline & $\mathrm{C}=\mathrm{C}$ & HIS $362(\mathrm{~A})$ & $\pi-\pi$ & \\
\hline \multirow{5}{*}{7} & $\mathrm{NH}_{2}$ & O SER 235 (A) & H- acceptor & \multirow{5}{*}{-17.4} \\
\hline & $\mathrm{NH}$ & O PRO 232(A) & H- acceptor & \\
\hline & $\mathrm{C}=\mathrm{O}$ & N HIS 362(A) & $\pi-\mathrm{H}$ & \\
\hline & 6-ring & SER 235(A) & $\pi-\mathrm{H}$ & \\
\hline & $\mathrm{C}=\mathrm{C}$ & HIS 398(A) & $\pi-\pi$ & \\
\hline \multirow{6}{*}{ Donepezil } & $-\mathrm{OCH}_{3}$ & NH HIS 398 (A) & H- acceptor & \multirow{6}{*}{-10.6} \\
\hline & & O PRO 232(A) & H- acceptor & \\
\hline & 6-ring & N PHE 284(A) & H- donor & \\
\hline & & ARG 289(A) & $\pi-\mathrm{H}$ & \\
\hline & $\mathrm{C}=\mathrm{C}$ & HIS 362(A) & $\pi-\pi, \pi-S i$ & \\
\hline & & PRO 361(A) & $\pi-\pi$ & \\
\hline
\end{tabular}

favorable binding energies suggests that these compounds could be used as clinically effective inhibitors for the AChE enzyme.

\section{Biological Evaluation}

\section{Acetylcholinesterase inhibition assay}

Inhibitory activity of the newly synthesized compounds was screened in vitro for their anti-AChE activity. Electric eel AChE was used as the target enzyme. Meanwhile, donepezil hydrochloride was used as a reference compound. The obtained data are listed in Table 1. The first test tried to study the effect of DMSO solvent, which no longer exhibited any inhibitory effect [28]. Then examine the 6, 7 in the mixture at exceptional concentrations $\left(10^{-4}, 10^{-6}, 10^{-8}, 10^{-10}\right.$, and $\left.10^{-12} \mathrm{M}\right)$. Before every set of inhibition experiments was conducted, the AChE activity was measured using four distinct concentrations of acetylthiocholineiodide substrate $(0.02$, 0.04, 0.06, and $0.08 \mathrm{M}$ ) in a healthy subject in Fig. 6.

The impact of distinct concentrations of every inhibitor at acetylcholine concentrations on $\mathrm{AChE}$ undertaking is illustrated in Fig. 7. As clear in Fig. 3, the 6 and 7 compounds had low inhibition effect on AChE activity at low concentrations $\left(10^{-12} \mathrm{M}\right)$, but at high concentrations $\left(10^{-6}\right.$ and $\left.10^{-4} \mathrm{M}\right)$ and middle concentrations $\left(10^{-10}\right.$ and $\left.10^{-8} \mathrm{M}\right)$ of two compounds had high inhibition effect on AChE. The biochemical tests indicated that two prepared compounds have caused noticed inhibitory effects on enzyme activity compared with the measured control values of $2.5 \mu \mathrm{mol} / 2 \mathrm{~min} / \mathrm{mL}$, see Table 2.

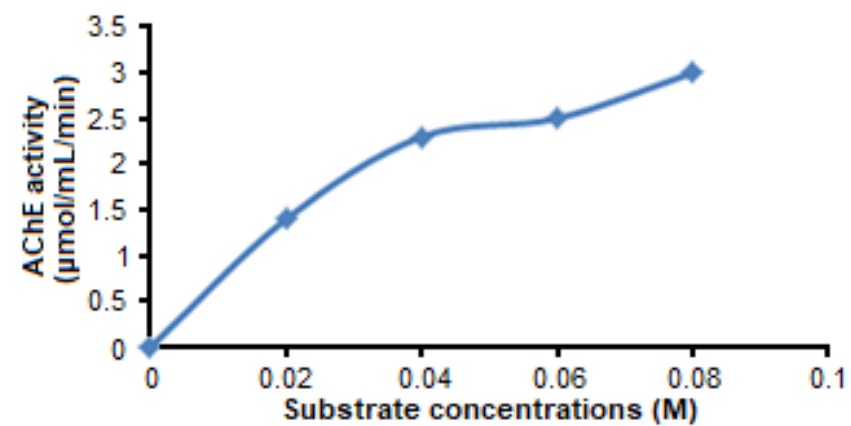

Fig 6. The hyperbolic curve of $\mathrm{AChE}$ at variant concentrations of AChTI and in the absence of inhibitor 
From these results, it is clear that $\mathbf{6}$ and $\mathbf{7}$ inhibited AChE activity in healthy samples. Table 2 showed that the more significant inhibition percent was found at $10^{-4}$ and $10^{-10} \mathrm{M}$ concentrations, and low inhibition was obtained at $10^{-12}$ and $10^{-4} \mathrm{M}$ in 6 and 7 , respectively. These can be attributed to the presence of six common interactions. First, the benzocumarin ring interacts with the phenyl of the Trp286 indole by a $\pi-\pi$ interaction-the nitrogen atom of pyrimidine forms a hydrogen bond with the hydroxy of Tyr124. Second, the carbonylphenyl ring creates a $\pi-\pi$ interaction with the indole of Trp86. This carbonyl substituent is also essential for polar interactions. Third, the phenoxy group forms two hydrogen bonds with the carbonyl of Gly120 by acting as a hydrogen donor. Finally, the hydroxy of the Tyr 133 acts as a hydrogen acceptor or may create another hydrogen bond with the carbonyl of Glu202.

Our work could not be compared exactly to other work because, as far as we know, this is the only study that demonstrates the effects of new prepared coumarins derivatives on the activities of AChE enzyme activity. However, Abdul-Rida et al. [23] concluded that the tested coumarin derivatives are potential candidates as leads for potent and efficacious ChEs inhibitors. The assayed compounds exhibited moderate inhibitory activity against AChE, with $\mathrm{IC}_{50}$ values ranging from $1.828-8.252 \mathrm{mM}$.

\section{Study Type of Inhibition}

The second part of this study is to decide the type of inhibition and kinetic parameters $\left(\mathrm{K}_{\mathrm{m}}, \mathrm{V}_{\max }\right.$, and $\left.\mathrm{K}_{\mathrm{i}}\right)$ at extraordinary substrate concentrations and beneath the same stipulations. Lineweaver-Burk's graph showed that ( 6 and 7 inhibit AChE by different types of inhibition and gave a different value of $\mathrm{K}_{\mathrm{i}}$. The results are summarized in Table 3 and Fig. 8.

The study indicated that $\mathrm{K}_{\mathrm{m}}$ was varied from same or less in the presence of prepared compounds compared with the non-inhibiting system. A low $\mathrm{K}_{\mathrm{m}}$ means the higher affinity of the substrate toward enzyme

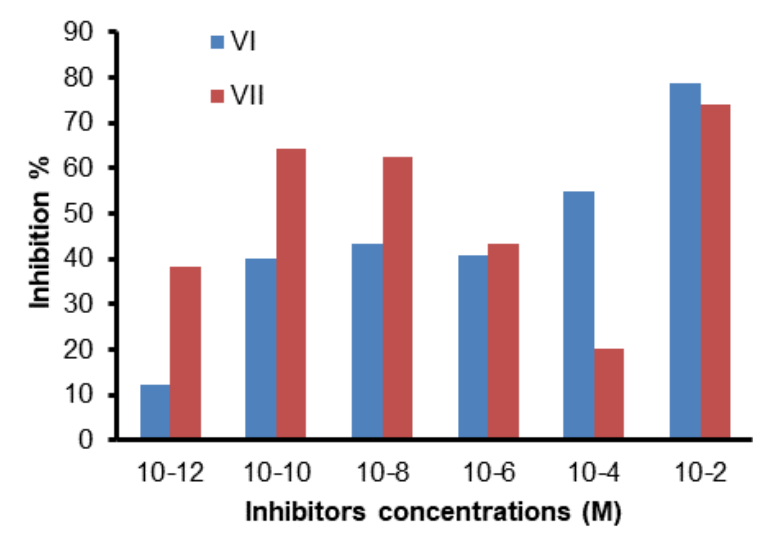

Fig 7. Effect of different concentrations of 6 and 7 compounds on $\mathrm{AChE}$ activity represented as a percent of inhibition

Table 2. Effect of different concentrations of 6 and 7 in sera of normal subjects on the AChE activity

\begin{tabular}{lccc}
\hline Samples & Inhibitor conc. $(\mathrm{M})$ & AChE activity $(\mu \mathrm{mol} / 2 \mathrm{~min} / \mathrm{mL})$ & \% Inhibition \\
\hline control & zero & 2.5 & - \\
\hline \multirow{6}{*}{$\mathbf{6}$} & $10^{-2}$ & 0.533 & $78.68^{\star}$ \\
& $10^{-4}$ & 1.128 & 54.88 \\
& $10^{-6}$ & 1.48 & 40.8 \\
& $10^{-8}$ & 1.42 & 43.2 \\
& $10^{-10}$ & 1.5 & 40 \\
\hline \multirow{6}{*}{7} & $10^{-12}$ & 2.199 & 12.04 \\
\hline $10^{-2}$ & 0.652 & $73.92^{\star}$ \\
& $10^{-4}$ & 2 & 20 \\
& $10^{-6}$ & 1.42 & 43.2 \\
& $10^{-8}$ & 0.937 & 62.52 \\
& $10^{-10}$ & 0.89 & 64.41 \\
\hline
\end{tabular}

* Excluded in the kinetic study due to turbid solution 
Table 3. The kinetic parameters of AChE with and without inhibitors in sera of healthy subjects

\begin{tabular}{lllllll}
\hline \multirow{2}{*}{ Sample } & & Inhibitor conc. $(\mathrm{M})$ & $\mathrm{K}_{\mathrm{m}}(\mathrm{M})$ & $\begin{array}{l}\mathrm{V}_{\max } \\
(\mu \mathrm{mol} / 2 \mathrm{~min} / \mathrm{mL})\end{array}$ & $\mathrm{K}_{\mathrm{i}}(\mathrm{M})$ & Inhibition type \\
\hline \multicolumn{2}{l}{ Control } & Zero & 0.05 & 5 & - & - \\
\hline \multirow{2}{*}{6} & Maximum inhibition & $10^{-4}$ & 0.05 & 2.77 & $1.25 \times 10^{-4}$ & $\mathrm{Non}$-comp \\
& Minimum inhibition & $10^{-12}$ & 0.041 & 3.33 & $1.99 \times 10^{-12}$ & $\mathrm{Un}$-comp \\
\hline \multirow{2}{*}{7} & Minimum inhibition & $10^{-4}$ & 0.04 & 3.44 & $2.2 \times 10^{-4}$ & $\mathrm{Un}$-comp \\
& Maximum inhibition & $10^{-10}$ & 0.033 & 2.63 & $1.1 \times 10^{-10}$ & Un-comp \\
\hline
\end{tabular}

*Non-comp: noncompetitive inhibition

Un-comp: uncompetitive inhibition
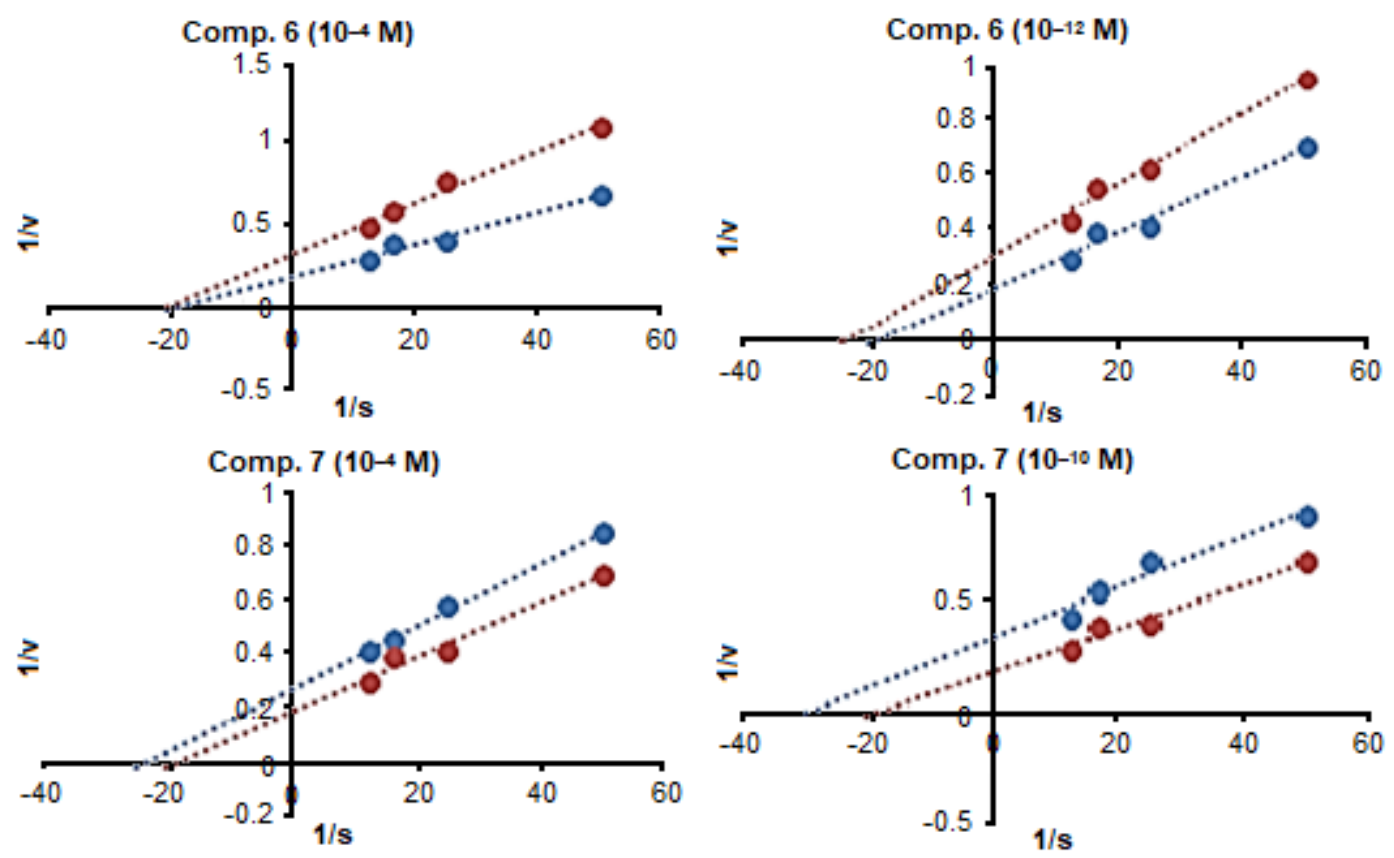

Fig 8. Lineweaver-Burk graphs at four different AChTI concentrations at maximum and minimum inhibition concentrations of 6 and 7 in healthy and patient samples

and the lower affinity of inhibitors to fits into the activesite cleft of the enzyme, which is present in $\mathbf{6}$ at concentrations of $10^{-12} \mathrm{M}$ and in 7 at concentrations of $10^{-4}$ and $10^{-10} \mathrm{M}$ (uncompetitive inhibition). On the other hand, 10-4 $\mathrm{M}$ concentrations do not compute with a substrate on the enzyme's active site (noncompetitive inhibition). The affinity is influenced by several factors, such as size, three-dimensional structure, and the presence of metals imidazole complexes that easily bind non-covalently to the active site. AChE showed inhibition constant $\mathrm{K}_{\mathrm{i}}$ in the range of $10^{-4}-10^{-12} \mathrm{M}$ in the presence of maximum and minimum inhibitors concentrations, probably due to variant types of inhibition from non and uncompetitive.
Table 3 clearly showed that the $\mathrm{V}_{\max }$ value for the control sample $(5 \mathrm{KU} / \mathrm{L})$ was higher than in inhibited samples. So, it is clear that the amount of active enzyme $\mathrm{V}_{\max }$ is present in the non-inhibited system. Ilkay et al. [29] showed AChE inhibitory activities of seven coumarin derivatives (umbelliferone (1), 4methylumbelliferone (2), 4-hydroxycoumarin (3), scopoletin (4), 8-methoxy psoralen (5), bergapten (6), and iso-bergapten (7)). A furanocoumarin mixture obtained from Heracleum crenatifolium Boiss (Umbelliferae), as well as two anthraquinone derivatives (rhein (8) and aloe-emodine (9)) and one stilbene, rhapontin (10), were tested by the spectrophotometric method of Ellman using an ELISA microplate-reader at 
$1 \mathrm{mg} / \mathrm{mL}$. Among them, the furanocoumarin mixture $(68.8 \pm 0.76 \%)$, bergapten $(62.4 \pm 0.74 \%)$, aloe-emodine $(57.2 \pm 1.32 \%)$, scopoletin (53.1 $\pm 0.83 \%)$, and 4-methyl umbelliferone $(62.3 \pm 1.03 \%)$ showed over $50 \%$ inhibition against AChE. The distinction in $\mathrm{K}_{\mathrm{i}}$ values allows us to conclude that no longer all of the assumptions underlying basic Michaelis-Menten equations are being obeyed and that the facts are steady with the kinetics of a tight-binding inhibitor. Also, the outcomes demonstrated that $\mathbf{6}$ and $\mathbf{7}$ exhibit different sorts of inhibition at maximum and minimum concentration. The combined inhibition by using 6 and 7 in most inhibition can explain for to inhibitors structure that makes conformational modifications after binding to $-\mathrm{SH},-\mathrm{COOH}$, imidazole groups of Ser, His, and Glu in AChE, which is both localized in the active core or is essential in deciding the energetic conformation of the enzyme molecule.

On the other hand, noncompetitive inhibition can be defined according to the classical models described that the inhibitor binds to the allosteric site that reasons conformational trade lock the enzyme and prevents the substrate binding or lowering substrate affinity to AChE. Baruah et al. [30] found that inhibit AChE in an anoncompetitive manner with Chromenyl Coumarate showing the highest inhibition potency. Sequestration of the inhibitors by human serum albumin rendered the reduction in AChE inhibition activity. Therefore, a potential AChEI is expected to bind with AChE strongly but with a lower tendency to be confiscated in HSA.

\section{- CONCLUSION}

In conclusion, novel benzo[f]coumarin derivatives bearing various pyrimidines were synthesized with good yields via cyclocondensation of chalcone 4 with urea, thiourea, and guanidine $\mathrm{HCl}$ in the presence of glacial acetic acid. The synthesized compounds were screened against Acetylcholinesterase activity. The obtained results revealed that the benzocoumarin derivatives conjugated with various pyrimidines contain substituted groups ($\mathrm{OH},-\mathrm{S}$, and $-\mathrm{NH})$. It showed that $\mathbf{6}$ and $\mathbf{7}$ inhibit AChE activity in healthy samples. The more significant inhibition percent was found at $10^{-4}$ and $10^{-10} \mathrm{M}$ concentrations, while the low inhibition was obtained at $10^{-12}$ and $10^{-4} \mathrm{M}$ in 6 and 7 , respectively.

\section{- ACKNOWLEDGMENTS}

The authors are very thankful and gratefully to Department of Chemistry, College of Education, University of Al-Qadisiyah for support in providing necessary facilities. We also wish to thank Dr. Najim A. Al-Masoudi for his sustain guidance to complete this work.

\section{- REFERENCES}

[1] Tran, L., and Ha-Duong, T., 2015, Exploring the Alzheimer amyloid- $\beta$ peptide conformational ensemble: A review of molecular dynamics approaches, Peptides, 69, 86-91.

[2] Terry, A.V., and Buccafusco, J.J., 2003, The cholinergic hypothesis of age and Alzheimer's disease-related cognitive deficits: Recent challenges and their implications for novel drug development, J. Pharmacol. Exp. Ther., 306 (3), 821-827.

[3] Knopman, D.S., Petersen, R.C., and Jack, C.R., 2019, A brief history of "Alzheimer disease": Multiple meanings separated by a common name, Neurology, 92 (22), 1053-1059.

[4] Alipour, M., Khoobi, M., Moradi, A., Nadri, H., Moghadam, F.H., Emami, S., Hasanpour, Z., Foroumadi, A., and Shafiee, A., 2014, Synthesis and anti-cholinesterase activity of new 7hydroxycoumarin derivatives, Eur. J. Med. Chem., 82, 536-544.

[5] Ali, M.Y., Jannat, S., Jung, H.A., Choi, R.J., Roy, A., and Choi, J.S., 2016, Anti-Alzheimer's disease potential of coumarins from Angelica decursiva and Artemisia capillaris and structure-activity analysis, Asian Pac. J. Trop. Med., 9 (2), 103-111.

[6] Anand, P., and Singh, B., 2013, A review on cholinesterase inhibitors for Alzheimer's disease, Arch. Pharm. Res., 36 (4), 375-399.

[7] Sahoo, C.R., Sahoo, J., Mahapatra, M., Lenka, D., Sahu, P.K., Dehury, B., and Paidesetty, S.K., 2021, Coumarin derivatives as promising antibacterial agent(s), Arabian J. Chem., 14 (2), 102922. 
[8] Chen, Z., Bi, J., and Su, W., 2013, Synthesis and antitumor activity of novel coumarin derivatives via a three-component reaction in water, Chin. J. Chem., 31 (4), 507-514.

[9] Hassan, A.Y., Sarg, M.T., El Deeb, M.A., Bayoumi, A.H., and El Rabeb, S.I., 2018, Facile synthesis and anticancer activity study of a novel series of substituted and fused coumarin derivatives, $J$. Heterocycl. Chem., 55 (6), 1426-1443.

[10] Sairam, K.V., Gurupadayya, B.M., Vishwanathan, B.I., Chandan, R.S., and Nagesha, D.K., 2016, Cytotoxicity studies of coumarin analogs: Design, synthesis and biological activity, RSC Adv., 6 (101), 98816-98828.

[11] Jaber, Q.A.H., Abdul-Rida, N.A., and Adnan, S., 2020, Boosting $3 H$-benzo[f]chromen-3-one chalcone with anti-inflammatory drugs: Synthesis, characterization, and evaluation of cytotoxicity and antimicrobial activity, Russ. J. Org. Chem., 56 (9), 1622-1627.

[12] Lei, L., Xue, Y., Liu, Z., Peng, S., He, Y., Zhang, Y., Fang, R., Wang, J., Luo, Z., Yao, G., Zhang, J., Zhang, G., Song, H., and Zhang, Y., 2015, Coumarin derivatives from Ainsliaea fragrans and their anticoagulant activity, Sci. Rep., 5 (1), 13544.

[13] Ghate, M., Kusanur, R.A., and Kulkarni, M.V., 2005, Synthesis and in vivo analgesic and antiinflammatory activity of some bi heterocyclic coumarin derivatives, Eur. J. Med. Chem., 40 (9), 882-887.

[14] Basanagouda, M., Jadhav, V.B., Kulkarni, M.V., and Rao, R.N., 2011, Computer aided prediction of biological activity spectra: Study of correlation between predicted and observed activities for coumarin-4-acetic acids, Indian J. Pharm. Sci., 73 (1), 88-92.

[15] Hassan, M.Z., Osman, H., Ali, M.A., and Ahsan, M.J., 2016, Therapeutic potential of coumarins as antiviral agents, Eur. J. Med. Chem., 123, 236-255.

[16] Hu, X.L., Gao, C., Xu, Z., Liu, M.L., Feng, L.S., and Zhang, G.D., 2018, Recent development of coumarin derivatives as potential antiplasmodial and antimalarial agents, Curr. Top. Med. Chem., 18 (2), 114-123.
[17] Chen, L.Z., Sun, W.W., Bo, L., Wang, J.Q., Xiu, C., Tang, W.J., Shi, J.B., Zhou, H.P., and Liu, X.H., 2017, New arylpyrazoline-coumarins: Synthesis and anti-inflammatory activity, Eur. J. Med. Chem., 138, 170-181.

[18] Chougala, B.M., Samundeeswari, S., Holiyachi, M., Naik, N.S., Shastri, L.A., Dodamani, S., Jalalpure, S., Dixit, S.R., Joshi, S.D., and Sunagar, V.A., 2018, Green, unexpected synthesis of bis-coumarin derivatives as potent anti-bacterial and antiinflammatory agents, Eur. J. Med. Chem., 143, 1744-1756.

[19] Wang, S.B., Liu, H., Li, G.Y., Li, J., Li, X.J., Lei, K., Wei, L.C., Quan, Z.S., Wang, X.K., and Liu, R.M., 2019, Coumarin and 3,4-dihydroquinolinone derivatives: Synthesis, antidepressant activity, and molecular docking studies, Pharmacol. Rep., 71 (6), 1244-1252.

[20] Bai, Y., Li, D., Zhou, T., Qin, N., Li, Z., Yu, Z., and Hua, H., 2016, Coumarins from the roots of Angelica dahurica with antioxidant and antiproliferative activities, J. Funct. Foods, 20, 453-462.

[21] Al-Amiery, A.A., Al-Majedy, Y.K., Kadhum, A.A.H., Mohamad, A.B., 2014, New coumarin derivatives as an eco-friendly inhibitor of corrosion of mild steel in acid medium, Molecules, 20 (1), 366-383.

[22] Xu, Z., Chen, Q., Zhang, Y., and Liang, C., 2021, Coumarin-based derivatives with potential antiHIV activity, Fitoterapia, 150, 104863.

[23] Yusufzai, S.K., Khan, M.S., Sulaiman, O., Osman, H., and Lamjin, D.N., 2018, Molecular docking studies of coumarin hybrids as potential acetylcholinesterase, butyrylcholinesterase, monoamine oxidase $\mathrm{A} / \mathrm{B}$ and $\beta$-amyloid inhibitors for Alzheimer's disease, Chem. Cent. J., 12 (1), 128.

[24] Abdul-Rida, N.A., Adnan, S., and Jaber, Q.A.H., 2020, Development of novel imaging fluorescent agents bearing anti-inflammatory drugs: Synthesis, structural characterization and evaluation of biological activity, Russ. J. Bioorg. Chem., 46 (4), 620-626.

[25] Matos, M.J., Vilar, S., Gonzalez-Franco, R.M., Uriarte, E., Santana, L., Friedman, C., Tatonetti, 
N.P., Viña, D., and Fontenla, J.A., 2013, Novel (coumarin-3-yl)carbamates as selective MAO-B inhibitors: Synthesis, in vitro and in vivo assays, theoretical evaluation of ADME properties and docking study, Eur. J. Med. Chem., 63, 151-161.

[26] Ellman, G.L., Courtney, K.D., Andres, V., and Featherstone, R.M., 1961, A new and rapid colorimetric determination of acetylcholinesterase activity, Biochem. Pharmacol., 7 (2), 88-95.

[27] Rizvi, S.M.D., Shakil, S., and Haneef, M., 2013, A simple click by click protocol to perform docking: AutoDock 4.2 made easy for non-bioinformaticians, EXCLI J., 12, 831-857.
[28] Nabil, Z., 2015, Kinetics for the inhibition of serum acetylthiocholin esterase activity by some prepared phenobarbital derivatives, Int. J. Biochem. Res. Rev., 7 (2), 100-111.

[29] Ilkay, O., Fatma, T., and Bilge, S., 2008, Coumarin, anthroquinone and stilbene derivatives with anticholinesterase activity, Z. Naturforsch., C: Biosci., 63 (5-6), 366-370.

[30] Baruah, P., Basumatary, G., Yesylevskyy, S.O., Aguan, K., Bez, G., and Mitra, S., 2018, Novel coumarin derivatives as potent acetylcholinesterase inhibitors: Insight into efficacy, mode and site of inhibition, J. Biomol. Struct. Dyn., 37 (7), 1-52. 